\title{
Impressões e compreensões \\ sobre uma comunidade rural na Amazônia, Brasil
}

Ricardo Agum Ribeiro(a)

Sávio Luis Stoco ${ }^{(b)}$

Alessandra Ferreira Dales Nava(c)

Sully de Souza Sampaio(d)

Leandro Luiz Giatti(e)

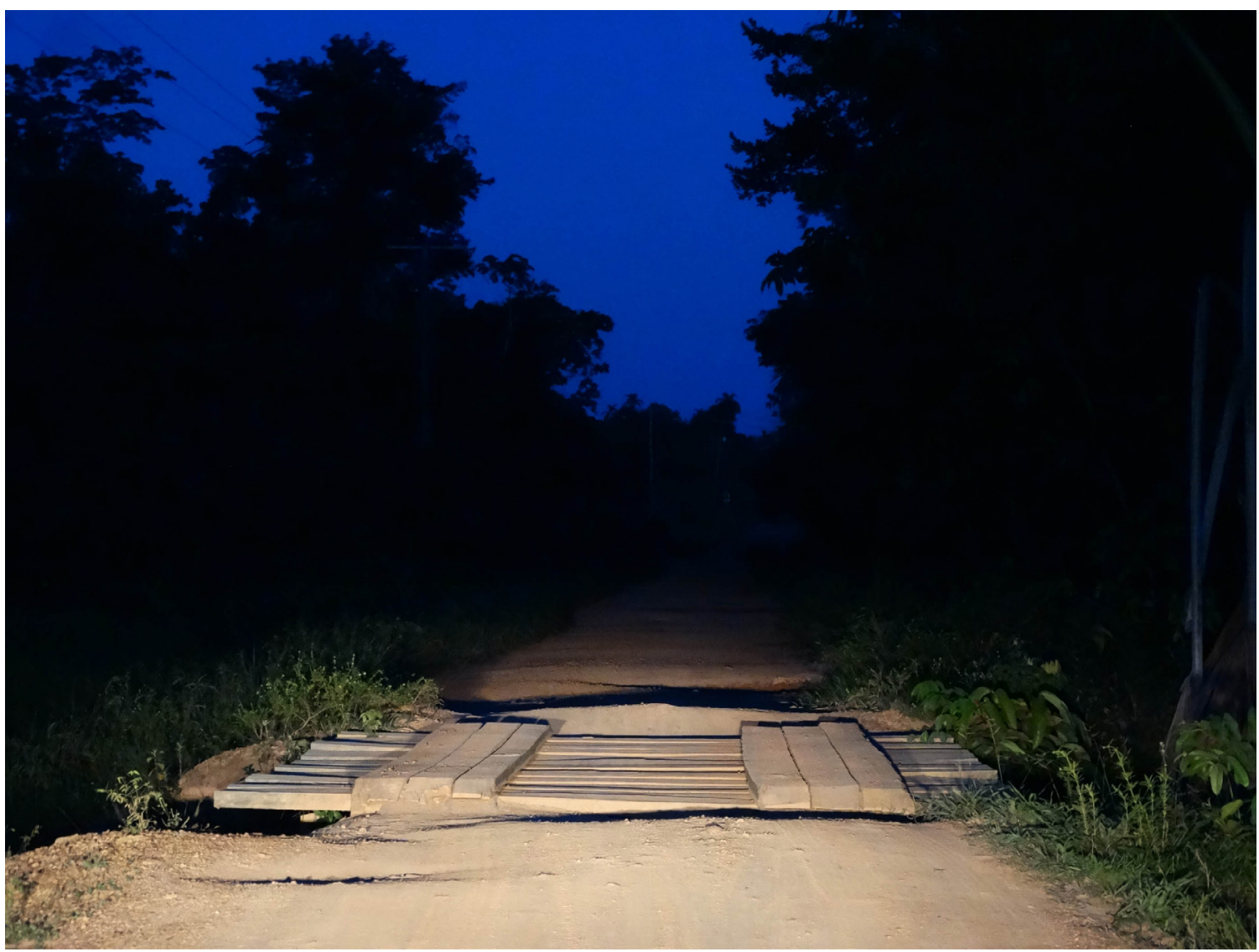

A pluralidade do itinerário a percorrer nos caminhos formados pelos novos ramais de piçarra abertos no assentamento rural de Rio Pardo, no município amazonense de Presidente Figueiredo, bem poderia ser tomada como metáfora da busca por captar esta comunidade por meio de um ensaio fotográfico (a) Laboratório de Situação de Saúde e Gestão do Cuidado às Populações em Situação de Vulnerabilidade (SAGESC), Fundação Oswaldo Cruz (Fiocruz)

Amazônia. Bolsista de Desenvolvimento Científico Regional,

Conselho Nacional

de Desenvolvimento Científico e Tecnológico e Fundação de Amparo à Pesquisa do Estado do Amazonas (FAPEAM).

Rua Teresina, 476, Adrianópolis. Manaus, AM, Brasil. 69057070. ricardoagum@ yahoo.com.br

(b) Doutorando, Programa de Pós-Graduação Meios e Processos Audiovisuais da Escola de Comunicação e Artes, Universidade de São Paulo (ECA-USP). Bolsista da Fundação de Amparo à Pesquisa do Amazonas. São Paulo, SP, Brasil. saviostoco@gmail.com

(c) Fiocruz Amazônia.

Bolsista Tec-Tec FAPEAM/ Fiocruz. Manaus, AM Brasil.navaveterinaria@ gmail.com

(d) Cientista social. Bolsista Tec-Tec FAPEAM/Fiocruz. Manaus, AM, Brasil. sullysampaio@gmail.com

(e) Departamento de Saúde Ambiental, Faculdade de Saúde Pública, USP. São Paulo, SP, Brasil. Igiatti@usp.br 
em um projeto de criação coletivo e interdisciplinar ${ }^{(f)}$, e que se propunha, metodologicamente, evitar um roteiro preestabelecido.

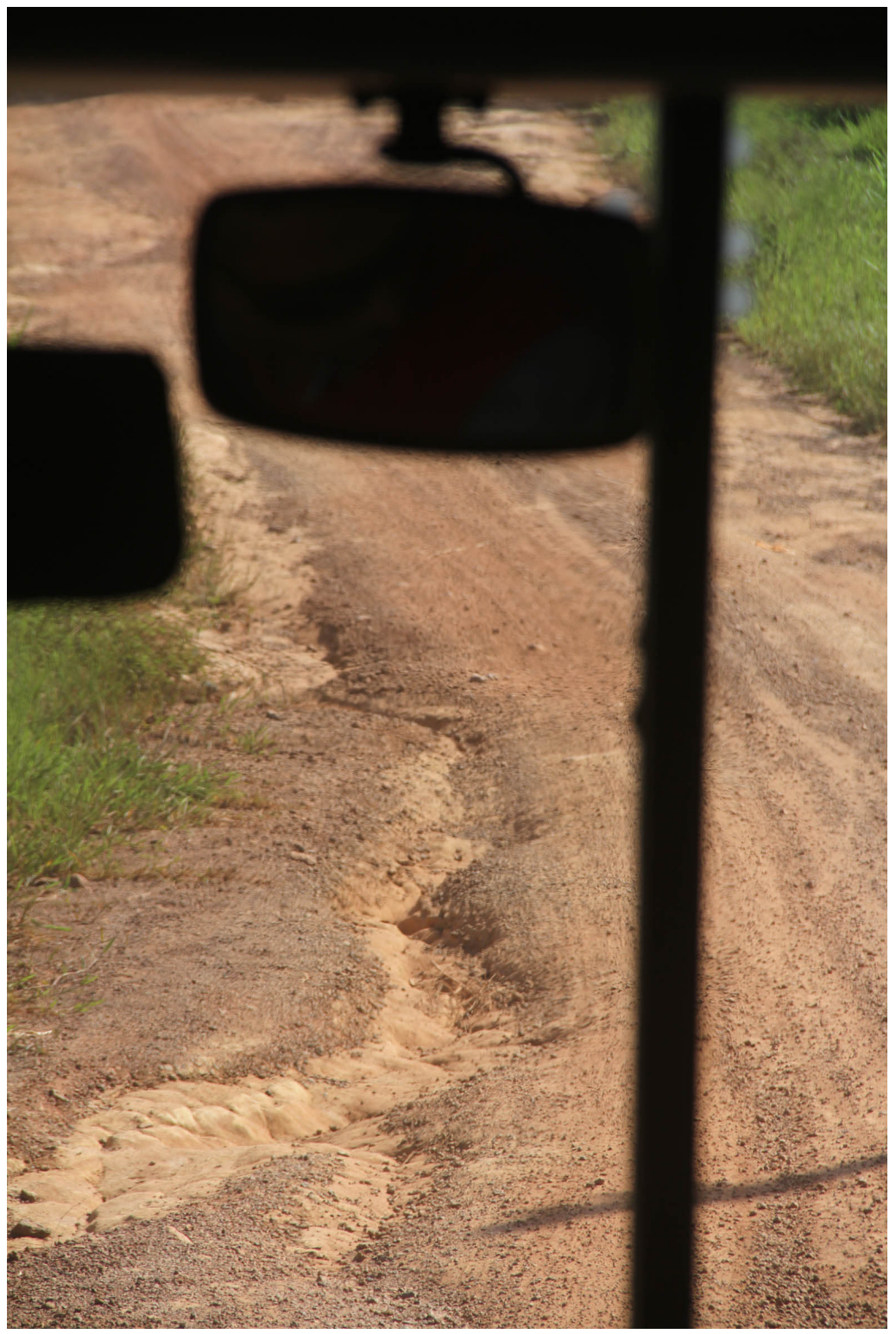

Essa abordagem buscou da seguinte maneira se fazer desviante. Primeiro, buscando se elaborar, a partir do diretamente visto e apreensível, sem que as imagens fossem tratadas com menor importância em relação às ideias. E, em seguida, buscando alinhavar a narrativa visual, englobando as ideias, por vezes heterogêneas, partilhadas entre os nove pesquisadores-fotógrafos de distintas formações ${ }^{(g)}$ - ao invés de um olhar unilateral que, no caso, se tivesse essa sido a maneira de produção, corresponderia ao ponto de vista de um único fotógrafo, com sua "autonomia" preservada. (f) As imagens apresentadas foram produzidas, em 2015 com o apoio do Edital Amazônia Cultural 2013 do Ministério da Cultura e do Edital Pop C\&T 2015 da Fundação de Amparo à Pesquisa do Amazonas - FAPEAM. O trabalho é parte do projeto Visão Pardo, em que um grupo de pesquisadoresfotógrafos, oriundos de distintas formações,

e que regularmente utilizam fotografias como instrumento complementar a suas pesquisas, compôs um grupo artístico denominado Coletivo PARDO, na busca de construir uma narrativa da comunidade de Rio Pardo por meio da fotografia, capaz de permear e integrar os olhares disciplinares.

(g) Os créditos de todas as imagens serão concedidos ao Coletivo PARDO, que tem como componentes para o projeto: Alessandra Nava; Danielle Ferreira; Leandro Giatti; Márcio Rodrigues; Ricardo

Agum; Rodrigo Mexas; Sávio Stoco; Sérgio Coelho e Sully Sampaio. 
(h) Neste processo de reunião dos acervos, nas leituras coletivas que promovíamos a partir dos resultados de fotógrafo, tivemos situações em que imagens que, inicialmente, eram consideradas falhas, puderam ser reavaliadas conjuntamente e inseridas.

(i) Usamos o termo "narrativa" tanto em sua sugestão a acontecimentos a serem percebidos em continuidade, quanto de forma não linear, mas dispostos um após o outro.

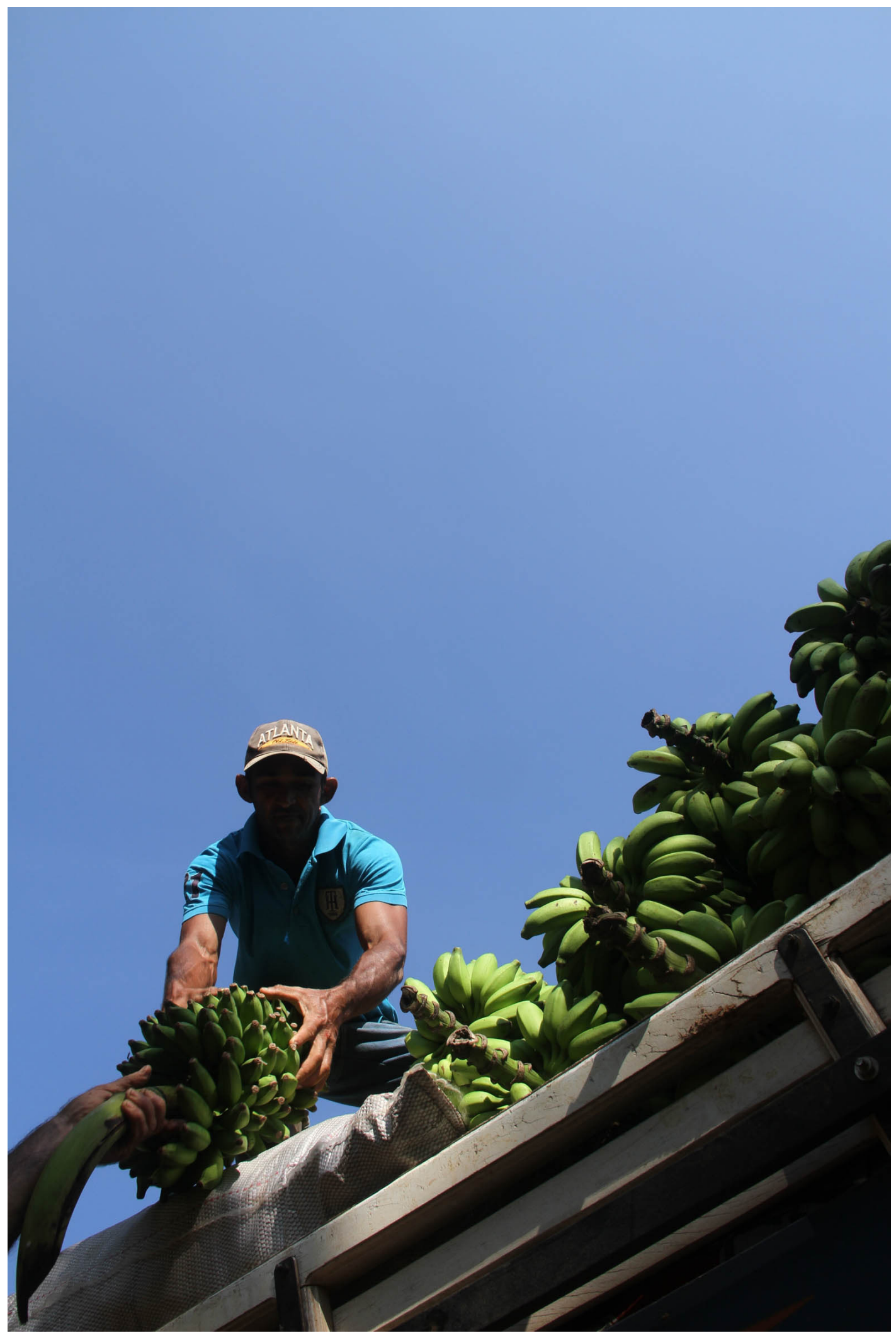

Por outro lado, as indicações iniciais aos pesquisadores-fotógrafos foram no sentido de estimulá-los a seguirem quaisquer que fossem suas orientações formais para a produção das imagens. Na etapa de edição e composição final(h) a ideia seria ter à disposição um emaranhado instigante de rotas-imagens a fim de pavimentarmos uma narrativa ${ }^{(i)}$ em conjunto. 

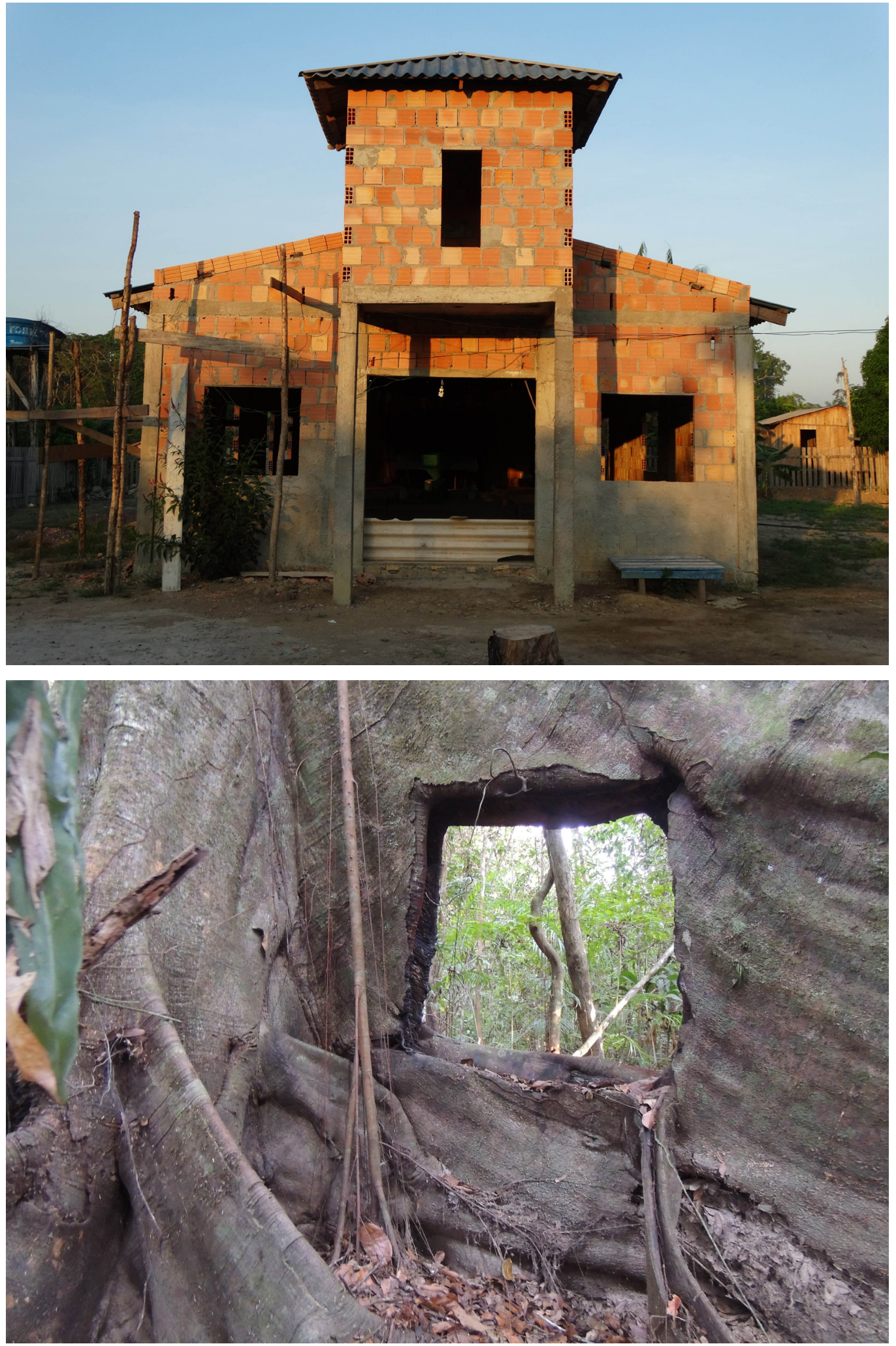

316 อ) Interface comunicaçä́o saúde educação 2018;22(64):313-24 
(j) A princípio entendemos que, neste texto, o autor se refere ao ensaio literário, mas, pela

forma aberta também poderíamos levar as considerações para outras

linguagens artísticas ou de expressão.
Prezando pela especificidade diversa deste grupo reunido, fomos entendendo o valor de integrarmos a interdisciplinaridade na elaboração de um discurso ensaístico sobre Rio Pardo, e que isso fosse moldando e enriquecendo nosso imaginário sobre o local. Lembrando que defrontar o acúmulo dos conhecimentos que as disciplinas científicas dispõem atualmente, tal como esclarece Jean Starobinski a seguir, seria uma marca de distinção dos discursos ensaísticos contemporâneos ${ }^{(j)}$. Ele indica um primeiro movimento de "tirar partido" justamente do montante de reflexões, noções, formas de estudar e compreender certos objetos que as disciplinas desenvolvem, para que a inquietação ensaística possa ser implantada e desenvolvida neste cadinho:

Vê-se que se trata de tirar o melhor partido dessas disciplinas, de aproveitar tudo o que elas podem oferecer, e, em seguida, tomar distância delas, uma distância de reflexão e de liberdade, para sua própria segurança e para a nossa. O desafio, então, é não ficar em débito com o que as ciências humanas, em sua linguagem impessoal (ou aparentemente impessoal), são capazes de revelar, ao estabelecer relações controláveis, derivadas de estruturas exatas. Não convém, no entanto, limita-se a isto. Essas relações, essas estruturas constituem o material que devemos orquestrar em nossa língua pessoal, com todos os riscos e perigos. ${ }^{1}$ (p. 23)

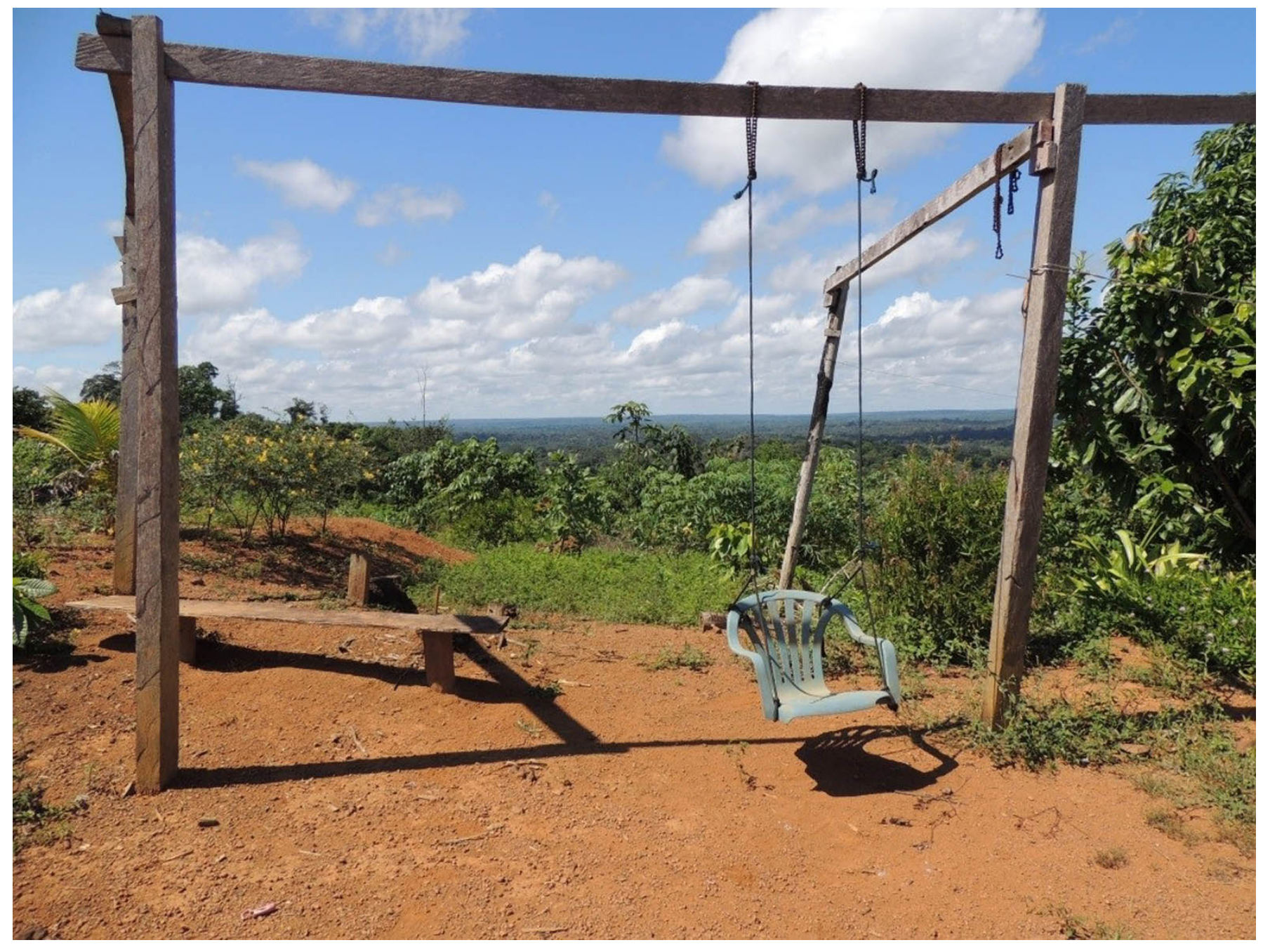




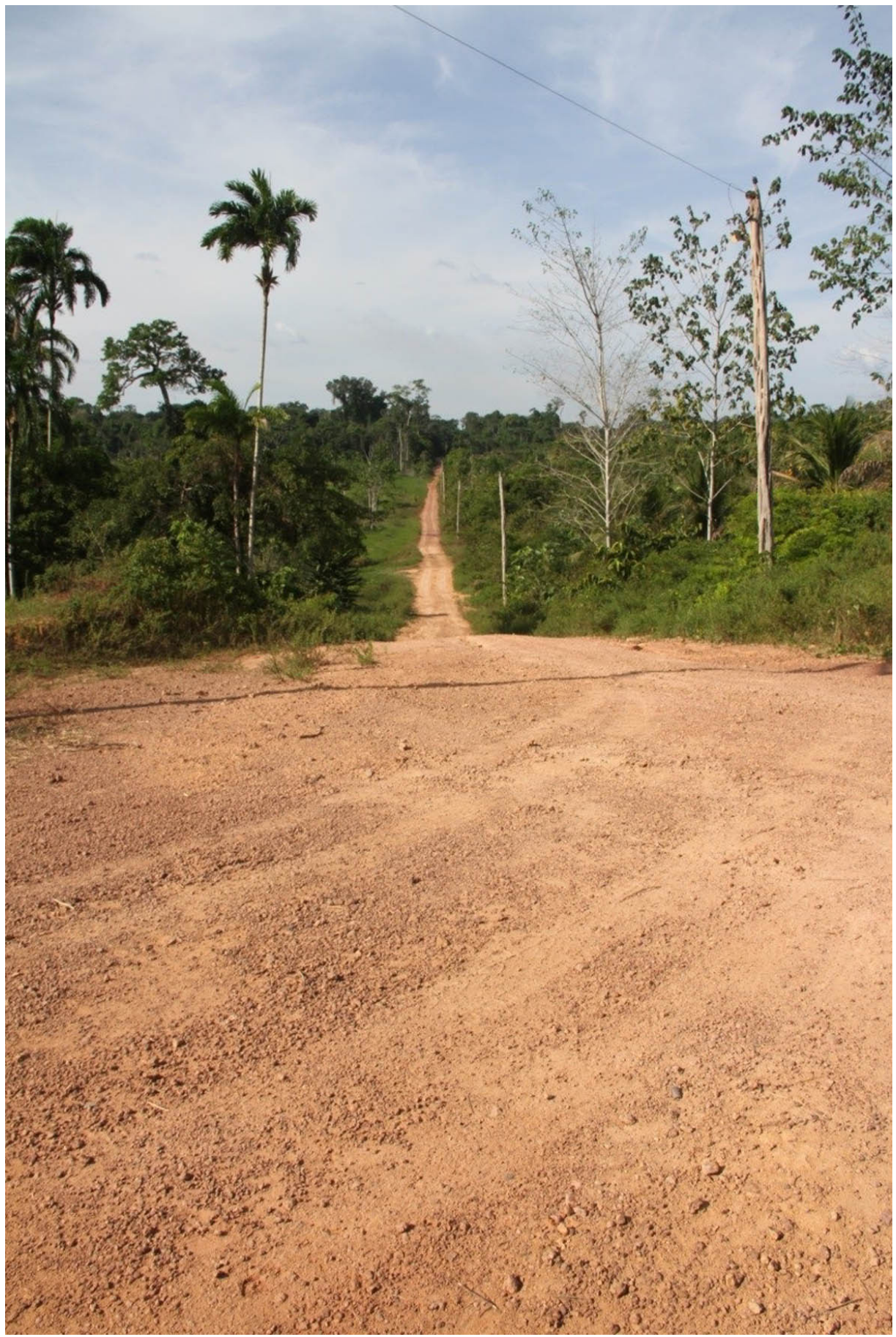

E buscando não nos limitarmos à bagagem científica do grupo, o processo que ocorreu também em contraponto ao que pudesse ser entendido como uma ideia fixa, predeterminada e impositiva, talvez vindo da "pesquisa exaustiva séria"(k). Emprenhamo-nos, a partir dos deslocamentos literais, pelos ramais e cursos d'água, mas, sobretudo, a partir dos encontros com moradores de Rio Pardo, aqueles que habitam e moldam aquele espaço que nem sempre foi planejado ou idealizado por eles próprios(l). (k) Termo tomado de empréstimo de Starobinski ${ }^{1}$ (p. 15) no seguinte trecho: "A Universidade, no apogeu de seu período positivista, tendo fixado as regras e os cânones da pesquisa exaustiva séria, rechaça o ensaio e o ensaísmo às trevas exteriores, com o risco de banir, no mesmo movimento, o brilho do estilo e as audácias do pensamento. Visto da sala de aula, avaliado pelo júri de tese, o ensaísta é um amáve amador que vai juntar-se ao crítico impressionista na zona suspeita da nãocientificidade" "

(l) O Assentamento Rural de Rio Pardo é fruto de uma intervenção do INCRA (Instituto Nacional de Colonização e Reforma Agrária), que, na década de 1990 . demarcou a área e a destinou para famílias interessadas em terras para cultivo. No entanto, passadas algumas décadas, as famílias ainda resistem, pela implementação tímida de ações de infraestrutura no local. As cerca de duzentas famílias providenciam, em grande parte, as melhorias que seriam de competência do ente governamental. 
(m) Mary Louise Pratt ${ }^{2}$ desenvolve a noção de "zona de contato", "compreendido como sinônimo de fronteira cultural, enfatizando as dimensões interativas e improvisadas dos encontros coloniais, pondo em questão como os sujeitos coloniais são constituídos nas e pelas relações entre colonizadores e colonizados, ou viajantes e visitados, em termos de interação e trocas no interior de relações assimétricas de poder"

(p. 283).
Sendo que, ali, tínhamos como objetivo uma síntese proveniente dos olhares interdisciplinares dos fotógrafos (viajantes) e da interação com os "visitados"; e, por conseguinte, reconhecendo a existência de "zonas de contato", ou "fronteiras culturais" $(\mathrm{m})$ - que tentamos serem, ao máximo, valorizadas e equilibradas, distintamente de processos exploratórios passados que abundam na tradição científica, entre outras, na região amazônica, e no Brasil e colônias como um todo. Uma das ideias era a de que a iniciativa colaborasse para tentar superar, ou amenizar, a forte carga desta tradição à qual todos nós, inevitavelmente, nos ligamos, estando entre os que trabalham e produzem ciência hoje.
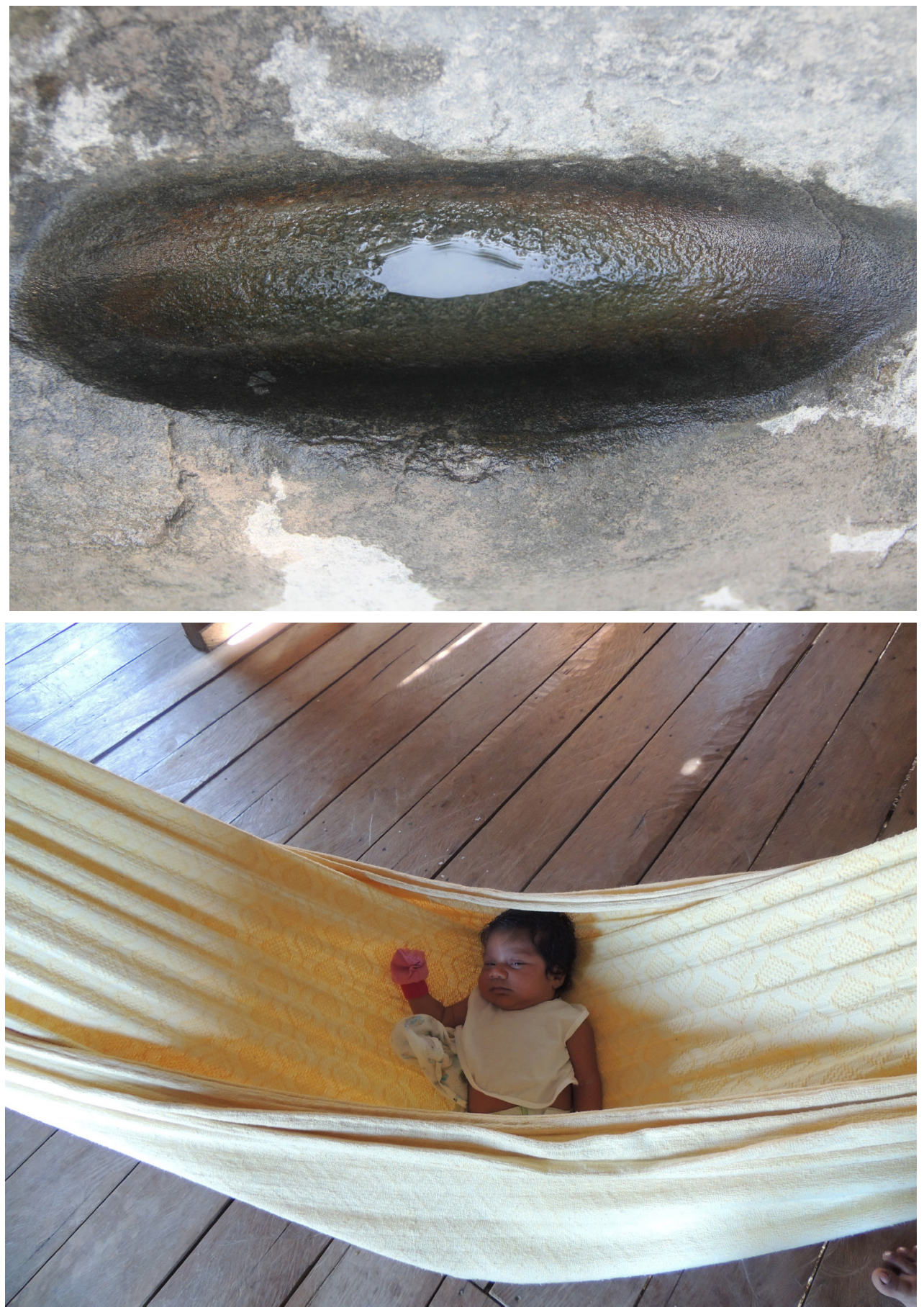
Neste sentido, novamente, as considerações sobre o ensaísmo na contemporaneidade se referem à via de mão dupla que emerge a partir do encontro, nos disponibilizando a aproveitar essa experiência à criação discursiva:

Partindo de uma liberdade que escolhe seus objetos, que inventa sua linguagem e seus métodos, o ensaio, nesse limite ideal em que apenas ensaio concebê-lo, deveria aliar ciência e poesia. Ele deveria ser, ao mesmo tempo, compreensão da linguagem do outro e invenção de uma linguagem própria; escuta de um sentido comunicado e criação de relações inesperadas no seio do presente. [...] o ensaio nunca deve deixar de estar atento à resposta precisa que as obras ou os eventos interrogados devolvem às nossas questões. ${ }^{1}$ (p. 23-4, grifo nosso)

Esteticamente, voltamos à ideia de uma proposta aberta. No lugar da subscrição a um estilo ou estética fotográfica, a mistura de imagens de fatura mais documentais ou outras mais, digamos, subjetivantes. As experimentações também foram almejadas por meio da atenção ao sequenciamento, promovendo um desenrolar de ideias visuais, e justaposição de duplas de imagens (dípticos), buscando elaborar, por assim dizer, terceiras noções resultantes do que é possível ser entendido com essas aproximações.

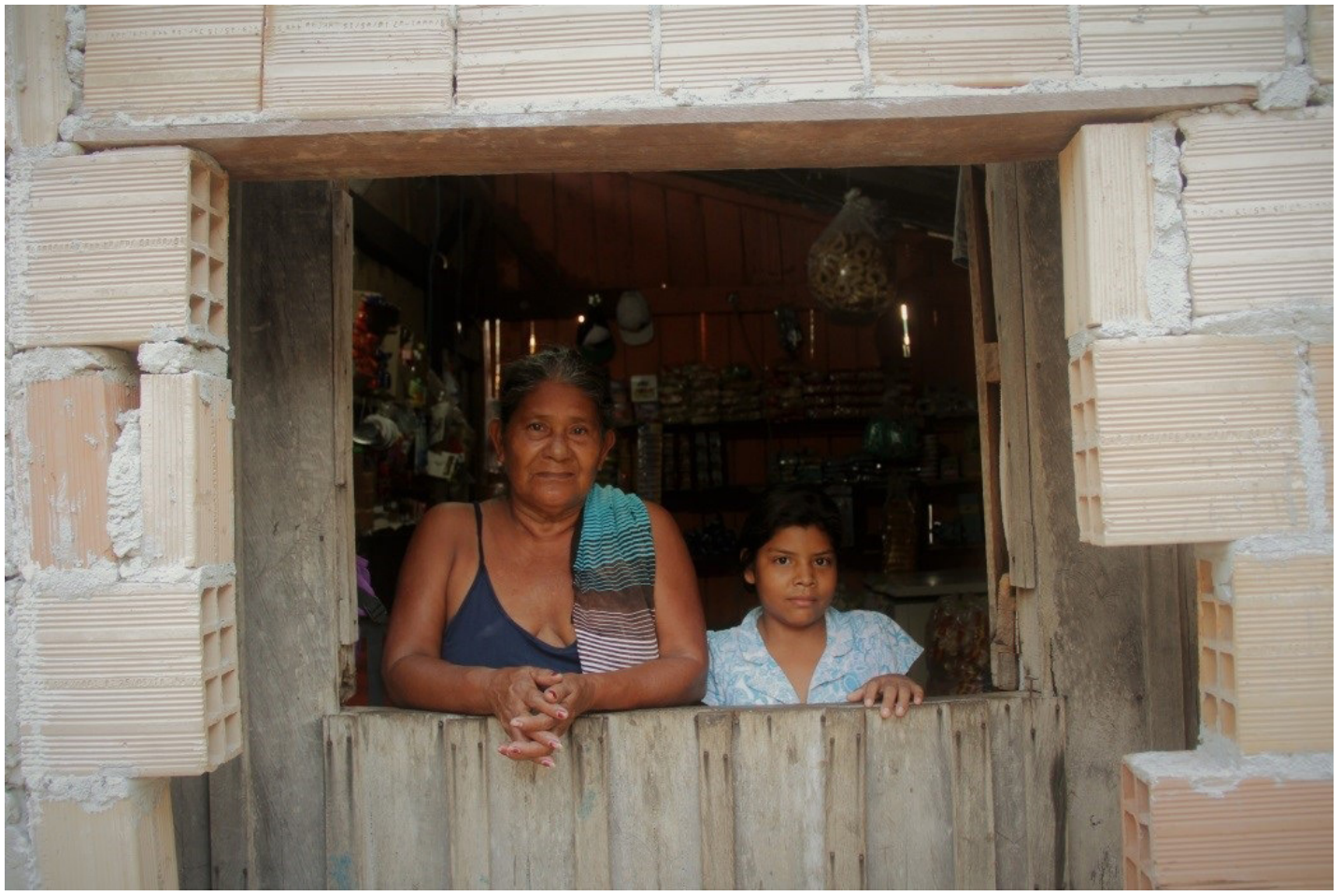


(n) Tadeu Chiarelli (apud Klautau-Filho ${ }^{3}$, p. 303-4) considera que "[...] podese pensar que o interesse que muitos fotógrafos demonstram, sobretudo hoje em dia, em produzir narrativas fotográficas acoplando duas ou mais imagens -, tenha a ver, justamente, com esse caráter sempre remissivo da fotografia. Talvez eles pensem que, formando pequenos agrupamentos, estejam suprindo de maneira mais sintética as mesmas lacunas da imagem fotográfica, que os mobilizam a realizar ensaios".

(o) Grifo nosso
Com esses recursos, buscamos dialogar com certas experiências contemporâneas na criação fotográfica ${ }^{(n)}$, e nos empenhando, também, no que Starobinski considera imprescindível para o ensaio, ou seja, o trabalho criativo com a linguagem que, mesmo no caso de buscar interações com conhecimentos de outras disciplinas, busca um discurso particular:

Em nenhum momento ele deve romper seu compromisso com a clareza e a beleza da linguagem. Enfim, chegada a hora, o ensaio deve soltar as amarras e tentar, por sua vez, ser ele mesmo uma obra, de sua própria e vacilante autoridade. ${ }^{1}$ (p. 23)(o).

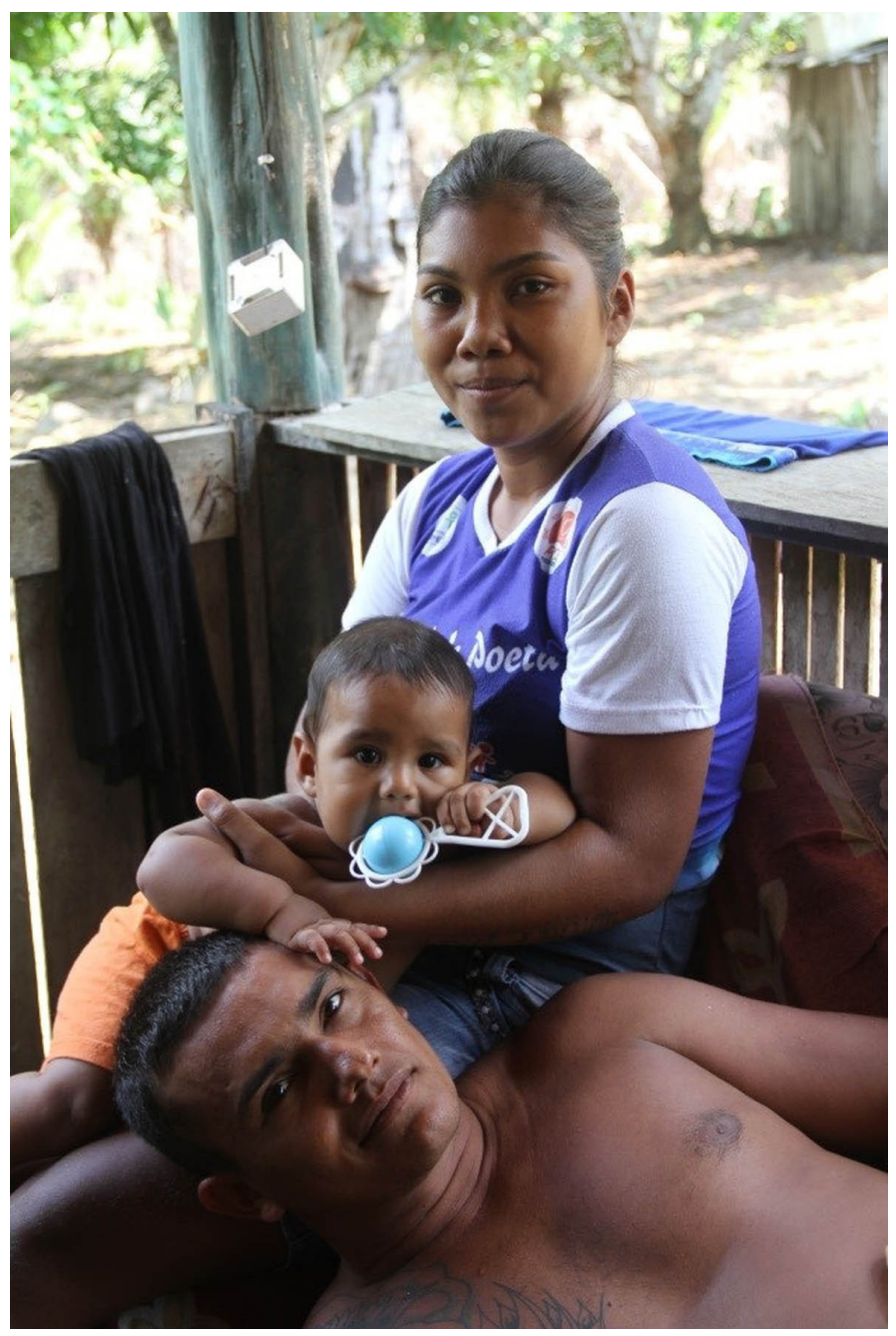


Concluindo, no trabalho de "pensar por imagens"(p) na comunidade de Rio Pardo, este espaço localizado entre o rural, a mata e uma urbanidade rural|,5, a "vacilante autoridade" de nosso discurso trilhou os ramais que se fazem perder de vista pela mata, mas que, no entanto, nos levaram ao encontro de vidas e suas histórias. Homens, mulheres, crianças, jovens e idosos que nos recepcionaram com invejável cordialidade. Nossas "descobertas" foram permitidas pelos moradores e moradoras de Rio Pardo, um convite para adentrar para além do umbral. Sem a aceleração e objetividade da reportagem, sem os controles metodológicos e com o interesse diverso do ensaio, nossa busca pela diluição da autoridade nos fez, por vezes, percorrer mais os caminhos dos conhecimentos daqueles que nos receberam em suas casas e quintais do que pelos métodos e conceitos das nossas ciências. (p) Expressão tomada de empréstimo de Samain ${ }^{6}$.

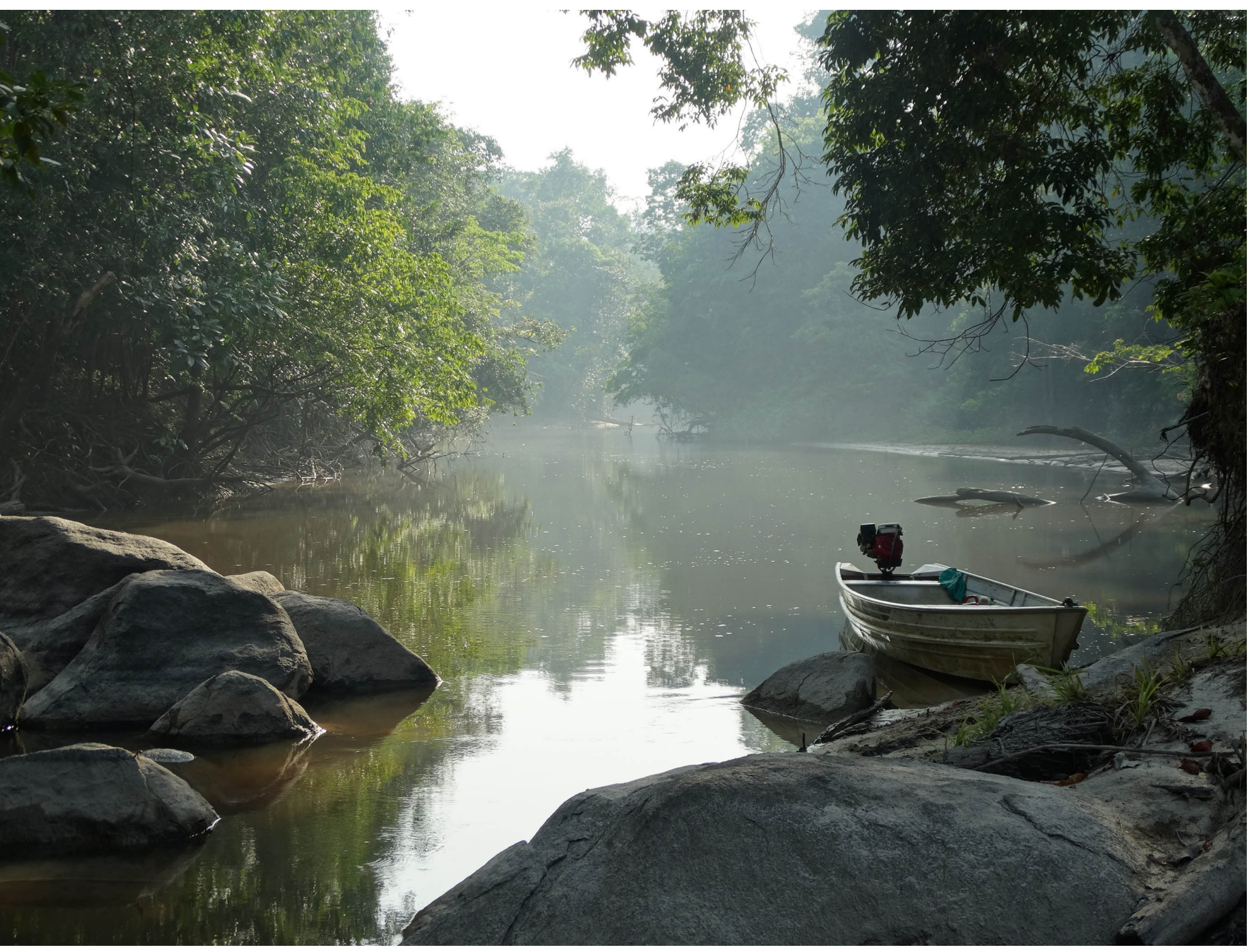



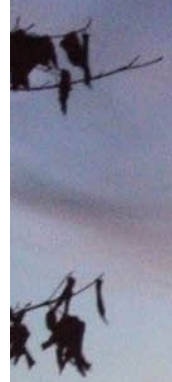

\section{Colaboradores}

Os autores Ricardo Agum Ribeiro, Sávio Luis Stoco e Leandro Luiz Giatti elaboraram a versão inicial do texto e fizeram a revisão bibliográfica. Alessandra Ferreira Dales Nava e Sully de Souza Sampaio realizaram revisões críticas e complementos. Todos os autores colaboraram com a produção das fotografias que ilustram o texto.

\section{Referências}

1. Starobinski J. É possível definir o ensaio?. Remate Males. 2012; 31(1-2):13-24.

2. Pratt ML. Os olhos do Império: relatos de viagem e transculturação. Bauru: Edusc; 1999.

3. Klautau-Filho M. A fotografia contemporânea e a poética de Miguel Rio Branco: imaterialidades do objeto, materialidades da imagem [tese]. São Paulo, SP: Escola de Comunicações e Artes, Universidade de São Paulo; 2011.

4. Agum R, Stoco S, Giatti LL. Visão Pardo. São Paulo: Ed. da Faculdade de Saúde Pública, Universidade de São Paulo; 2016.

5. Toledo RF, Giatti LL, Pelicioni MCF. Urbanidade rural, território e sustentabilidade: entre relações de contato de uma comunidade indígena no noroeste amazônico. Ambient Soc. 2009; 12(1):173-88.

6. Samain EG. Pensar por imagens. In: Peixoto CE, Souza, EC, Copque BA, Carvalho CAF. III Seminário Internacional Imagens e Narrativas, 2012, Rio de Janeiro. Imagens e narrativas. Rio de Janeiro: UERJ - Inarra; 2012. v.1, p. 309-34. 
Este artigo expressa - por meio de um ensaio fotográfico em um projeto fotográfico de criação coletivo e interdisciplinar - a busca por captar Rio Pardo, uma comunidade rural amazônica. Metodologicamente, a proposta evitou um roteiro preestabelecido baseando-se na noção de ensaísmo. Entre outros elementos, o trabalho foi executado, no geral, por fotógrafos de variadas formações acadêmicas, um caminho desafiador na intenção de apresentar a visão dos comunitários e evitar que as imagens fossem tratadas com menor importância em relação às ideias. Na etapa final, disporíamos de um emaranhado instigante de rotas-imagens para pavimentar nossa narrativa em conjunto.

Palavras-chave: Narrativa visual. Comunidade na Amazônia. Ensaio fotográfico. Interdisciplinaridade.

\section{Impressions and understandings of a rural community in the Amazon, Brazil}

This paper, which includes a photo essay as part of an interdisciplinary photographic project that was collectively created, is the expression of attempts to gather insights about Rio Pardo, a rural Amazonian community. The method proposed sought to avoid any predetermined script and was based on the notion of essay writing. Among its various components, the work was mainly carried out by photographers from different academic backgrounds, a route that was challenging but that aimed to present a vision of communities and avoid a situation in which the images would be considered less important than ideas. In the final phase, we had at our disposal an inspiring patchwork of routeimages that together paved our narrative.

Keywords: Visual narrative. Amazon community. Photo essay. Interdisciplinarity.

\section{Impresiones y comprensiones sobre una comunidad rural en la Amazonia, Brasil}

Este artículo expresa, por medio de un ensayo fotográfico en un proyecto fotográfico de creación colectiva e interdisciplinaria, la búsqueda por captar Rio Pardo, una comunidad rural amazónica. Metodológicamente, la propuesta evitó un itinerario preestablecido basándose en la noción de ensayismo. Entre otros elementos, el trabajo fue ejecutado, en general, por fotógrafos de diversas formaciones académicas, un camino desafiador con la intención de presentar la visión de los comunitarios y evitar que las imágenes fuesen tratadas con menor importancia en relación a las ideas. En la etapa final, dispondremos de un enmarañado instigador de rutas-imágenes para pavimentar nuestra narrativa en conjunto.

Palabras clave: Narrativa visual. Comunidad en la Amazonia. Ensayo fotográfico. Interdisciplinario. 